\title{
Managing brand identity: effects on the employees
}

\author{
Rafael Bravo \\ Department of Marketing Management \\ University of Zaragoza \\ Isabel Buil $^{\mathrm{a}}$ \\ Department of Marketing Management \\ University of Zaragoza \\ Email: ibuil@unizar.es \\ Leslie de Chernatony \\ Aston Business School \\ Aston University \\ Eva Martínez \\ Department of Marketing Management \\ University of Zaragoza \\ a (Corresponding author)
}

\section{Accepted for publication in International Journal of Bank Marketing}

\section{Acknowledgements}

The authors acknowledge the financial support of the I+D+I project ECO2013-41257-P from the Government of Spain and the project "GENERES" (Ref: S-09) from the Government of Aragon and the European Social Fund. Isabel Buil would also like to thank the financial support received from the Caja de Ahorros de la Inmaculada of Zaragoza and the DGA (CONSI+D) (Programa Europa XXI de Estancias de Investigación). Eva Martínez also thanks the financial support of the "Subprograma de estancias de movilidad de profesores e investigadores séniores en centros extranjeros de enseñanza superior e investigación, incluido el Programa Salvador de Madariaga" (Ref: PR2011-0352). 


\title{
Managing brand identity: effects on the employees
}

\begin{abstract}
Purpose: The main goal of this paper is to better understand the brand identity management process from the employees' perspective. Specifically, it explores how the different dimensions of brand identity management influence employees' attitudinal and behavioural responses.
\end{abstract}

Design/methodology/approach: An empirical study was carried out to test the proposed model. The sample consisted of 297 employees in the UK financial services sector. Hypothesis testing was conducted using partial least square regression (PLS).

Findings: Results indicate that effective brand identity management can increase employees' identification with their organisations. Specifically, the most influential dimension is the employee-client focus. Results also show that organisational identification is a key variable to explain job satisfaction, WOM and brand citizenship behaviour.

Research limitations: This study focuses on the UK financial sector. To explore the generalisability of results, replication studies among other sectors and countries would be useful. The cross-sectional nature of the study also limits its causal inference.

Practical implications: This study shows the importance of brand identity management to foster positive employee attitudes and actions that go beyond their job responsibilities. The model developed may help organisations analyse the impact of managerial actions, monitoring the potential effects of changes in brand identity management amongst employees.

Originality/value: Although numerous conceptual frameworks highlight the importance of brand identity management, empirical studies in this area are scarce. The current work extends previous research by empirically analysing the effects of the dimensions of brand identity management from the employees' perspective.

Keywords: Brand identity, employees, banks 


\section{Managing brand identity: effects on the employees}

\section{Introduction}

In recent years, brand identity management has increased its importance in both managerial practice and academic research. The global financial crisis, which severely affected the credibility of many organisations, has further enhanced the interest in this topic. Thus, to restore stakeholders' trust, managerial actions cannot be exclusively limited to brand activities targeting consumers and other external stakeholders; instead they also need to be based on internal brand building programmes, integrating all employees.

Employees are a crucial part of the brand identity management strategy. They play a central role especially in the services sector where customers usually have direct contact with staff. Due to the intangible nature of services, the quality of interactions, knowledge and commitment of employees determines the overall perception of customers towards the company brand (Papasolomou and Vrontis, 2006; Kimpakorn and Tocquer, 2010). Internal branding activities are, therefore, key to communicate and deliver the brand promise to customers (Punjaisri and Wilson, 2011). However, in comparison with other marketing expenditures, such as advertising, companies invest relatively little to ensure their employees transform brand messages into reality in terms of customers' experiences (Boone, 2000).

While significant work exists exploring internal branding activities as drivers of employees' favourable attitudes and behaviours (e.g. Burmann et al., 2009b; Punjaisri et al., 2009a; Punjaisri and Wilson, 2011; Du Preez and Bendixen, 2015), insights into brand identity management in particular are limited and still lack empirical evidence. As such, with some recent exceptions (Bravo et al., 2015a, 2015b; Coleman et al., 2015), most existing studies are principally theoretical (e.g. Burmann and Zeplin, 2005; Mukherjee and He, 2008; Burmann et al., 2009a; da Silveira et al., 2013) or based on case studies (e.g. Melewar and Akel, 2005; Ghodeswar, 2008; Konecnik and de Chernatony, 2013). Moreover, research in this field has often explored the perspectives of top management or brand consultants (Davies, 2008; Arendt and Brettel, 2010; Suvatjis et al., 2012; Coleman et al., 2015), ignoring how employees perceive the brand management process. Given that employees' perceptions can influence their attitudes and behaviours, and therefore affect customers' experiences (Schlager et al., 2011), it is especially useful to identify and measure the impact of brand management practices in the eyes of staff. 
The main goal of this study is, therefore, to gain a better understanding of the brand identity management process from the employees' perspective and to explore how the different dimensions of brand identity management influence employees' attitudinal and behavioural responses. Specifically, it investigates the effect of brand identity management dimensions, such as employee and client focus, visual identity, brand personality, consistent communications and human resource initiatives, on employees' organisational identification. In turn, the study examines the influence of organisational identification on key indicators in human resource and marketing management, such as job satisfaction, positive word-of-mouth (WOM) and brand citizenship behaviours.

This study focuses on an important sector: the financial services in the UK. In 2014, financial and insurance services contributed $£ 126.9$ billion in gross value added to the UK economy, which is approximately $8.0 \%$ of the UK's total gross value added and $3.4 \%$ of jobs (Library of the House of Commons, 2015). The financial sector has been notably damaged by recent problems of toxic assets, poor liquidity and bad practices by a few banks that have adversely affected financial services corporations. Furthermore, due to other external factors such as deregulation and increasing globalisation, the banking sector has faced diminishing consumer trust and confidence (Colton and Oliveira, 2009; Kuehner-Herbert, 2009). To restore consumer confidence, an inside out approach, where brand identity management plays a central role, is needed. In addition, given that employees are the embodiment of services brands, it is critical that managers recognise their important contributions in rebuilding brand confidence. Therefore, the study of brand identity management from employees' perspective in this sector is timely and pertinent.

This work contributes both to academic research and managerial practice. From an academic perspective, this study extends previous research on internal branding and responds to recent calls for additional research to further advance understanding of the effects of brand identity (Coleman et al., 2015). Specifically, the empirical analysis of this study complements insights from previous conceptual and recent empirical works, and sheds more light on how brand identity management can leverage employees' favourable responses. This research also adopts a particularly demanding perspective, that is, the analysis of employees' perceptions. In addition, this study explores the brand identity management concept integrating traditional issues such as visual elements and external communications, with new factors such as employee and customer focus and brand personality (Simoes et al., 2005; Arendt and Brettel, 2010; Coleman et al., 2011). The development and validation of a model of brand identity 
management, and its outcomes, can also help practitioners understand the importance of internal branding, and specifically the impact of the different dimensions of brand identity management on employees' attitudes and behaviours.

This paper is structured as follows. It opens with a general discussion of brand identity management. The conceptual model and hypotheses are presented. This is followed by the methodology and the analysis of empirical findings. Finally, the paper outlines the conclusions, implications and limitations of the research.

\section{Brand identity management}

Brand identity is an abstract concept that has been defined in several ways. The identity of a brand is usually based on its distinctive and durable core attributes (Albert and Whetten, 1985) that managers wish to develop and communicate. Aaker (1996) distinguishes between the core identity, comprising the central and timeless essence of the brand, and the extended identity, which includes other dynamic dimensions that may change as a consequence of different contexts. As such, he defines brand identity as "a unique set of brand associations that the brand strategist aspires to create or maintain” (Aaker, 1996, p. 68). Similarly, de Chernatony (2010) considers brand identity as the distinctive or central idea of a brand and how the brand communicates this idea to different stakeholders. In the same vein, Kapferer (2012) refers to brand identity as a brand's meaning projected by the firm.

Although emanating from brand managers, brand identity is further developed by other actors, such as employees and consumers (da Silveira et al., 2013). However, even if stakeholders' perceptions of a brand cannot be completely controlled by the organisation, there are factors that the company can manage, in order to transmit its brand identity and encourage favourable perceptions (Johnson and Zinkhan, 1990). In this sense, following Simoes et al. (2005), brand identity management can be defined as the activities implemented intentionally by the organisation to improve its image among both its external and internal audiences.

The creation of a strong brand identity has multiple benefits. Brand identity is an essential construct contributing to a sustainable competitive advantage and providing a basis for differentiation (e.g. Aaker, 1996; Kapferer, 2012). A well managed brand identity may result in positive stakeholder perceptions, attitudes and behaviours. The creation of a unique, coherent and distinctive identity can add value to the company's products (Coleman et al., 
2011) and increase consumers' preference and loyalty (Johnson and Zinkhan, 1990; Simoes et al., 2005). Likewise, brand identity can help companies increase the motivation of their employees and attract better and more qualified applicants, as well as greater investments (Van Riel, 1995; Arendt and Brettel, 2010).

Brand identity is a complex and multidimensional construct that has been studied from a wide range of disciplines. This multidisciplinary nature has led to a variety of conceptual frameworks, which have not been subject to empirical investigation. From marketing studies, which draw partly on organisational research (Bhattacharya and Sen, 2003; Simoes et al., 2005), there are different proposals as to what constitutes brand identity. For example, Aaker (1996) proposed a brand identity system based on twelve dimensions organised into four categories: brand as a product, an organisation, a person and a symbol. Kapferer (2012) introduced the brand identity prism, which comprises six dimensions: physique, personality, relationship, culture, self-image and reflection. From another perspective, de Chernatony (2010) conceives brand identity in terms of vision, culture, positioning, personality, relationships and presentation. Suvatjis et al. (2012) built on this and developed the sixstation model to guide brand identity building. The first station refers to leadership issues, the second to the strategy, the third to creativity, the fourth to communications, the fifth mainly refers to the staff and group dynamism and in the sixth station, the critical triplet station, the company's corporate personality, reputation and image is finally formed by external stakeholders.

Some recent empirical studies have focused on the analysis and measurement of brand identity management. Simoes et al. (2005) combine insights from the literature on visual identity, organisational studies and marketing to build their corporate identity management scale. This interdisciplinary approach leads the authors to develop a three-dimensional scale in the hotel sector which covers aspects related to the mission and value dissemination (i.e. how the information regarding the central values of the hotel is understood and shared by staff), consistent image implementation (i.e. how the communications and brand dimensions through various degrees of tangibility portray a specific image) and visual identity implementation (i.e. the degree to which specific activities are developed in the organisation to control the consistency and suitability of the visual elements). Building on these dimensions, Arendt and Brettel (2010) develop a model of brand identity management and its effects on brand image and firm performance. The main focus of their work, however, was not placed on the concept of brand identity management itself. Rather their key interest was to 
analyse the moderating effects of corporate social responsibility. More recently, Coleman et al. (2011) developed a scale of service brand identity. These authors propose a fivedimensional scale composed of employee and client focus, visual identity, brand personality, consistent communications and human resource initiatives. Given the key role of employees in services, this scale explicitly includes a dimension of employee and client focus that mainly reflects the degree to which employees are aware and respond to clients' needs and a dimension of human resource initiatives that refers to the activities of training which enable employees to deepen relationships with clients and monitoring employee performance. In addition, the visual identity dimension measures specific aspects of corporate visual identity systems, such as those related to the logo, font and the extent to which the corporate visual identity is helpful in making the organisation recognisable. Brand personality focuses on the favourability, strength, and uniqueness of the brand associations which brand personality can generate. Finally, the dimension of consistent communications refers to the organisation's understanding of the main marketing communication tools, as well as its ability to use these tools to present a consistent message.

\section{Conceptual framework and hypotheses}

This paper proposes a model to analyse the impact of brand identity management on employees' attitudes and behaviours in the financial services sector. Specifically, we analyse the dimensions of employee and client focus, visual identity, brand personality, consistent communications and human resource initiatives, and their effects on employees' organisational identification. We also explore the impact of organisational identification on job satisfaction. Finally, we investigate the effect of both organisational identification and job satisfaction on employees' positive WOM and brand citizenship behaviour. Figure 1 presents the conceptual framework.

\section{Insert Figure 1 about here}

Organisational identification is defined as "the individual's perception of oneness with, or belongingness to the organization" (Ashforth and Mael, 1989, p. 22). This construct has its origins in social identity theory (Tajfel and Turner, 1979; Mael and Ashforth, 1992). Social identity refers to the portion of an individual's self-concept derived from perceived 
membership of a relevant social group. Thus, according to this theory, an individual's selfconcept may be composed of different identities which evolve from social groups, such as the workplace.

The degree of identification will depend on the level to which employees perceive their organisation as part of their selves. When identification is strong, the individual's self-concept has incorporated a large part of what they believe is distinctive, central and enduring about the organisation into what they consider to be distinctive, central and enduring about their selves (Dutton et al., 1994). Likewise, the greater the identification, the more employees will act in accordance with group norms, values and goals of the organisation (van Knippenberg, 2000).

Brand identity management is a key driver of employees' degree of identification with the organisation (Johansson and Carlson, 2014). As such, a positive perception of the corporate brand identity and its management may help develop both a strong sense of attachment to the organisation and pride being part of the company (Dukerich et al., 2002; Bravo et al., 2015a). All the different dimensions that compose the analysis of brand identity management may have an effect on employees' identification with the organisation. Research on internal branding points to elements such as corporate values or human resources initiatives as crucial drivers of employees' identification (Punjaisri et al., 2009b). However, external dimensions, such as visual identity and corporate communications, may also play an important role. These dimensions present and represent the corporate brand to stakeholders, as well as helping employees internalise the brand and foster their identification (Bhattacharya and Sen, 2003).

Specifically, internal branding activities aimed at training employees and communicating the brand identity values to staff, may help them understand the corporate brand identity. These activities are crucial because they contribute to employees' internalisation of the brand values (Simoes et al., 2005), which may engender employees' identification with the company. Moreover, employees' perception of favourable, distinct and enduring images of the organisation through a well-managed employee-client focus strategy, through a consistent visual identity or through a clear brand personality could also contribute to forge organisational identification. Arendt and Brettel (2010) showed that a second-order construct of brand identity management composed of mission and value dissemination, consistent image implementation and visual identity exerts a positive effect on organisational identification. Punjaisri et al. (2009a, 2009b) also found empirically positive effects of internal branding elements on organisational identification in the hotel sector. In their work, 
internal branding was considered a second-order construct composed of human resource actions such as training and orientation programmes, and internal communications through group meetings and internal briefings.

Focusing on the financial services sector, Mitki et al. (2007) studied the changes in brand identity design in a subsidiary of an Israeli bank. These authors analysed the processes and activities that were carried out while designing and implementing these changes. They stressed the role played by aspects related to employee-client focus and human resource initiatives in the process of brand identity building. Thus, they indicated that the first step was to analyse the employees' and clients' perceptions of a bank's identity. This analysis helps to understand gaps between the actual and the ideal brand identity. In the brand identity building process, a thorough training programme is also needed to ensure that employees have assimilated the new corporate identity, as well as a periodic monitoring of employees' performance. This should help employees' internalisation of brand values, and therefore encourage employees' identification with their bank.

Other brand identity management dimensions such as brand communications, brand personality and visual identity may also be of importance to explain employees' identification with their bank. Pérez and Rodríguez del Bosque (2012) highlight the problem of stakeholders' scepticism towards banks during the financial crisis. These authors specifically analysed corporate social responsibility in banking and recommended financial organisations to place more effort on communicating these activities. Such communications, aimed both at the external and internal stakeholders, may favour stakeholders' identification with banks. Within the same sector, the work by Daffey and Abratt (2002) examined the brand identity management of a South African bank. The authors emphasised the need for "absolute rigidity" in the application of a single visual identity. They also stressed that staff must represent the personality of the brand. Similarly, in the Spanish banking context, Alloza (2008) and Bravo et al. (2015b) point to the employee-client strategy as a precursor of employees' identification, and also referred to the importance of other factors, such as communication, visual identity and brand personality to create a "single language" for the brand. All these dimensions of brand identity management present corporate brands to stakeholders and may foster employees' organisational identification. Therefore, based on the previous reasoning, we postulate: 
H1: Employees' perceptions of (a) an employee-client focus, (b) visual identity, (c) brand personality, (d) consistent communications, and (e) human resources initiatives have positive effects on organisational identification.

A potential outcome of organisational identification is job satisfaction (Berger et al., 2006; van Dick et al., 2004). From a general view, Hackman and Oldham (1980) refer to this concept as the degree to which an employee feels happy with his or her job. Similarly, Locke (1969) defines it as "the pleasurable emotional state resulting from the appraisal of one's job as achieving or facilitating the achievement of one's job values” (p. 316). Employees' attitude towards their job and tasks performed may depend on factors such as salary, relationships with co-workers and supervisors, type of work, autonomy, etc. The work by Brief (1998) points to two main factors: objective job circumstances and individuals' interpretations. Due to the variety of objective and subjective factors there may be situations where an employee is fairly satisfied with certain aspects of their job but not with other aspects. In this sense, job satisfaction could be analysed through employees' evaluation of all the different components of their job. However, the concept of job satisfaction in the literature is regarded as an overall attitude of an employee towards the job.

When employees identify themselves with their organisations, they tend to feel better about both themselves as part of the organisation and their jobs' characteristics. Even in adverse work conditions (e.g. low pay, salary reductions, etc), employees who score highly on organisational identification are more likely to see this situation as less troublesome (van Dick et al., 2004). This may be the case for instance when high organisational identification employees perceive the need to implement cut-backs to achieve the organisations' overall goals. Therefore, highly identified employees may perceive more positively (or less negatively) their job characteristics when they perceive these characteristics to be consistent with the organisational goals and identity. Similarly, when employees identify themselves with a company that has favourable attributes, they will feel satisfied and motivated in their jobs (Harris and de Chernatony, 2001; Wheeler et al., 2006). As such, we expect employees who highly identify themselves with their organisations will be more satisfied. Consequently, it is proposed that:

H2: Organisational identification has a positive effect on job satisfaction. 
Employees' willingness to spread positive WOM is a possible outcome of organisational identification and job satisfaction. Employees' positive WOM refers to the willingness to say positive things about the organisation and recommend it to others (King and Grace, 2010). WOM is generally defined as the oral and person-to-person communication between the receiver and the sender regarding brands, products or services (Arndt, 1967). WOM is particularly relevant for services, where a single recommendation can help convince a person to try a specific service provider (Gremler et al., 2001). In addition to customers, employees are also an important source of WOM. In this sense, Keeling et al. (2013) define staff WOM as "the process of staff and former employees communicating information and opinions about the organization, both within and beyond their social network” (p. 89).

Previous studies suggest that consumers' identification with a brand or an organisation has a positive impact on generating favourable WOM (Kuenzel and Halliday, 2008; Tuškej et al., 2013). Identification with a company increases the likelihood of conversations promoting a company to other consumers (Bhattacharya and Sen, 2003) and the recommendations of a company's products and brands (Ahearne et al., 2005; Algesheimer et al., 2005). All of this may also be applicable to employees as senders of positive WOM. Employees can spread positive recommendations about a corporate brand, not only as a provider of goods or services, but also as a good employer to those seeking jobs, or as a socially responsible company. This positive behaviour may be explained by two conditions. First, the employees' positive perceptions of the company and second, the employees' motivation to communicate these positive perceptions to internal and external audiences. Employees who identify with the organisation fulfil these two conditions as they perceive the company positively because it aligns with their own self-concepts. Moreover, highly identified employees are also motivated to make their relationship with the company visible by spreading positive WOM, because they are proud to be part of the organisation (Wheeler et al., 2006).

WOM is also considered a salient consequence of consumers' satisfaction (Brown et al., 2005). Therefore, in a similar way, employees who are satisfied are expected to spread positive comments about their organisation to others. The work by Lages (2012) explores the determinants of employees' expressions of favourable opinions about their workplace. Lages (2012), who refers to this behaviour as external representation of the workplace, empirically shows the key role played by job satisfaction influencing behaviour. Consequently, we propose:

H3: Organisational identification has a positive effect on employees’ WOM. 
H4: Job satisfaction has a positive effect on employees' WOM.

Finally, brand citizenship behaviour is an important organisational benefit that may result from both organisational identification and job satisfaction. Employees' behaviour is not limited to doing their best to fulfil their duties, but it goes further. In this sense, they may exhibit brand citizenship behaviours undertaking extra-role activities aimed at strengthening the brand identity and reaching the brand goals (Burmann and Zeplin, 2005). This behaviour is non-prescribed, that is, it is above and beyond the norm, yet is consistent with the organisation's values (King and Grace, 2012). The concept of brand citizenship behaviour is derived from organisational citizenship behaviour theory. Organisational citizenship behaviour (OCB) is defined by Organ $(1988$, p. 4) as "the individual behaviour that is discretionary, not directly or explicitly recognized by the formal reward system, and that in aggregate promotes the effective functioning of the organization". While both concepts share many commonalities, there are also differences between them. As indicated by Shaari et al. (2012), brand citizenship behaviour also considers the externally targeted behaviours such as strengthening the quality of brand-customers relationship. By contrast OCB is more focused on internal organisational tasks and job-related performance (Burmann and Zeplin, 2005).

Previous research suggests that organisational identification motivates efforts on behalf of the collective (Riketta, 2005; Van Dick et al., 2008). According to the social exchange theory, all human relationships are formed by the use of a subjective cost-benefit analysis and the comparison of alternatives (Homans, 1958). Amongst others, social exchange is based on reciprocation and on a justice principle. That is, the exchange must be reciprocal and fair (Searle, 1990). As such, when a company treats employees fairly, the employees will be satisfied and they will respond with fair and reciprocal behaviours in their work. If employees perceive the company is responsive, providing extra resources to employees, in turn employees will be likely to reciprocate with more effort (Lee and Allen, 2002). Therefore, employees who notably identify with their organisation will have a more positive attitude towards their job and this can result in a greater acknowledgement of the effort made by the company towards them. Consequently, they may be more willing to provide extra effort and behaviour beyond their job description (Isen and Baron, 1991). As indicated by van Dick et al. (2006), employees are more intrinsically motivated to engage in OCB if they identify more with their organisation. Moreover, employees satisfied with their job are more likely to accept and live the brand values of the organisation (Wu et al., 2008) and may be prone to engage in 
these behaviours as reciprocation for those who enhance their level of job satisfaction (Organ, 1988; Murphy et al., 2002; Riketta, 2008). In conclusion, organisational identification and job satisfaction may exert an influence on employees' brand citizenship behaviour. Building on these points, the following hypotheses are postulated:

H5: Organisational identification has a positive effect on employees’ brand citizenship behaviour.

H6: Job satisfaction has a positive effect on employees' brand citizenship behaviour.

\section{Method}

To test the proposed hypotheses, an empirical study was undertaken in 2013 with employees of the main banks in the United Kingdom. The sample was gathered from a UK database provided by an international market research consultancy. Individuals working in the banking sector were invited to participate in the study and were asked to complete an online questionnaire. Specifically, respondents were told that two European Universities were surveying employees working in leading companies in the banking sector in the UK with the aim of learning more about how financial services organisations manage the internal brand building process. Respondents were asked to answer all the questions, thinking about the bank for which they work, and were assured of anonymity. After eliminating invalid responses, the final sample consisted of 297 individuals. At the time of carrying out the study, respondents came from the following banking institutions in the UK: Barclays (20.2\% of respondents), Lloyds TSB (12.8\%), HSBC (10.8\%), RBS (8.1\%), Natwest (8.1\%), Halifax (6.7\%), Santander UK (6.7\%), Bank of Scotland (4.0\%), and others (22.6\%). Table 1 presents a demographic profile of the respondents.

\section{Insert Table 1 about here}

Well-established scales were employed to measure the constructs in this study (see Table 2). In all cases, seven-point Likert scales were used. Brand identity management was measured using the scale developed by Coleman et al. (2011). This scale, informed by extant scale development procedures, consists of a set of 15 items and measures employees' perceptions of five dimensions. Employee and client focus, with items including "Our bank 
treats every employee as an essential part of the organisation" and "Our bank makes an effort to discover our clients' needs"; visual identity, with items including "The corporate visual identity is helpful in making our bank recognisable”; brand personality, with items including "The associations making up our brand personality are extremely positive"; consistent communications, with items including "The people managing our communications programme have a good understanding of the strengths and weaknesses of all major marketing communications tools"; and human resource initiatives, with items including "Our employee training programmes are designed to develop skills required for acquiring and deepening client relationships”. Organisational identification, which relates to the sense of belonging of employees to the organisation, as well as their sense of pride and ownership, was measured using 3 items adapted from Punjaisri et al.'s (2009b) work. A sample item is "I feel I belong to this bank". Job satisfaction scale captures the level of satisfaction received by employees from their jobs, after realising what they want and value from their work. This construct was assessed following King and Grace (2010), with items including "I feel a great sense of satisfaction from my job". The items used to measure positive employee WOM were also extracted from the work by King and Grace (2010). This scale refers to the extent to which employees are willing to recommend the organisation to others and say positive things about the firm. Sample items include "I say positive things about my bank to others" and "I would recommend my bank to someone who seeks my advice”. Finally, the items that compose the scale of brand citizenship behaviour were derived from the works by Burmann and Zeplin (2005) and King and Grace (2010), measuring the extent to which employees undertake behaviours that are non-prescribed, but consistent with the organisations' brand values. Sample items include "I show extra initiative to ensure that my behaviour remains consistent with the brand promise of this bank".

\section{Insert Table 2 about here}

The potential existence of problems related to common method bias was controlled through procedural and statistical methods (Podsakoff et al., 2003). With regard to the former, ensuring confidentiality and anonymity reduced the possibility that the individuals responded artificially or in a dishonest manner. In addition, the design of the questionnaire tried to ensure that the respondents would not be able to establish cause-effect relationships between the dependent and the independent variables. With regard to the statistical procedures, all the 
constructs originally included in the questionnaire were subjected to exploratory factor analysis using EQS 6.1, which revealed a total of four factors with a maximum variance explained by a single factor of $17 \%$. This suggests that the items do not load on a general factor that accounts for the majority of the explained variance. A Harman's one-factor test by means of confirmatory factor analysis with EQS 6.1 also confirmed this finding. This test showed that the goodness of fit for a measurement model in which all the variables loaded on a single factor was substantially lower than the goodness of fit for a model where every item loaded on its corresponding latent variable. Thus, there is no evidence to suggest the presence of common method bias.

\section{Results}

The proposed model was examined using Partial Least Square (PLS) regression with SMART-PLS software. In comparison to traditional covariance-based structural equation modelling, this methodology is appropriate when the interest of the study focuses on prediction and on theory development rather than on strong theory confirmation (Reinartz et al., 2009). Accordingly, given the scope of this research, which focuses on predicting different dependent variables (i.e. job satisfaction, WOM and brand citizenship behaviour) and combines different theoretical frameworks, such as internal branding theories, social identity theory and social exchange theory, PLS seems to be particularly adequate. In addition, the use of PLS is preferable when the model, as in our case, includes a large number of indicators and latent variables and when the data is non-normally distributed (Chin, 2010; Ringle et al., 2012). Although PLS estimates both the measurement and structural models simultaneously, this analysis should be evaluated through two steps: analysis of the measurement model and analysis of the structural model.

Regarding the measurement model, factor loadings of the indicators for each construct were above 0.5 and were statistically significant which suggested convergent validity of the factors. The constructs also possess high internal validity. As is shown in Table 3, most of the Cronbach's Alpha values were above the critical threshold of 0.8. Moreover, composite reliability (CR) and average variance extracted (AVE) values were greater than the common thresholds of 0.7 and 0.5 , respectively (Hair et al., 2010). The only exception was the dimension of human resources initiatives, which has a Cronbach's Alpha value of 0.68. The reason behind this low value is that this reliability indicator is quite sensitive to the number of 
items. Due to this characteristic, and given that the rest of indicators have values above the usual thresholds, problems of reliability for this dimension were disregarded.

\section{Insert Table 3 about here}

Discriminant validity of the scales was analysed by comparing every construct's AVE with the squared correlation of that construct in relation to the rest of variables (Fornell and Larcker, 1981). In all cases, the AVE for any two constructs was always greater than the squared correlations and therefore discriminant validity was supported for the scales (see Table 4).

\section{Insert Table 4 about here}

To determine the statistical significance of the structural parameters, and to assess the proposed relationships, a bootstrap resampling technique with 5,000 subsamples was used. The structural model was examined through the significance of the coefficients $\lambda$ and $\beta$ and by observing the $\mathrm{R}^{2}$ values of the dependent variables. In this sense, all the factorial loadings of the different indicators on their respective latent variables were significant at $1 \%$. The $\mathrm{R}^{2}$ values were $0.58,0.61,0.70$ and 0.52 for organisational identification, job satisfaction, employee WOM and brand citizenship behaviour respectively. All of them were above the critical threshold of $10 \%$ (Falk and Miller, 1992). To evaluate the predictive relevance of the model, the Stone-Geisser test was used. In this test, the $\mathrm{Q}^{2}$ values for the dependent variables were positive. Therefore, it can be accepted that the dependent variables can be predicted by the independent variables and that the model presents predictive relevance.

We illustrate the results in Figure 2, and the findings are set out in Table 5. Results show that four of the five dimensions of brand identity management exert a positive and significant effect on organisational identification. Thus, the dimensions of employee-client focus $(\beta=0.35 ; \mathrm{p}<0.05)$, brand personality $(\beta=0.14 ; \mathrm{p}<0.05)$, consistent communications $(\beta=0.21$; $\mathrm{p}<0.05)$ and human resources initiatives $(\beta=0.23$; $<<0.05)$ determine the identification of the employee with the organisation. These results give support to H1a, H1c, H1d and H1e. Only 
the visual dimension of the brand identity does not affect this outcome significantly $(\beta=-0.08$; $\mathrm{p}>0.05)$.

Results also show that organisational identification exerts a positive and significant effect on job satisfaction $(\beta=0.78 ; \mathrm{p}<0.05)$, supporting hypothesis H2. Regarding the employees' WOM, both organisational identification $(\beta=0.54 ; \mathrm{p}<0.05)$ and job satisfaction $(\beta=0.34$; $\mathrm{p}<0.05$ ) have positive and significant effects on this outcome, which gives support to $\mathrm{H} 3$ and H4 respectively. The employees' willingness to spread positive WOM is, therefore, determined by their degree of identification with the bank and their satisfaction in their job. Finally, employees' brand citizenship behaviour is also explained by organisational identification $(\beta=0.68 ; p<0.05)$ which leads support to H5. However, job satisfaction does not exert a significant effect on this variable $(\beta=0.06 ; p>0.05)$, leading to reject H6. Thus, what determines the employees' brand citizenship behaviour is their identification with the bank. The implications of these results are discussed in the next section.

\section{Insert Figure 2 about here}

\section{Insert Table 5 about here}

\section{Discussion}

In the internal branding literature, there is little empirical research on the relationships between brand identity management and employees' responses. The present study proposes and tests a model to better understand these relationships.

From an overall view, the results show that a positive perception of brand identity management amongst employees may result in greater identification with the organisation for whom they work. Specifically, findings suggest that an employee and client focus exerts the highest influence on organisational identification. This empirical result supports the ideas of Mitki et al. (2007) and Alloza (2008) in their case studies, where they stress the importance of employees' participation in the design of bank identity. It is also in line with the work by Coelho and Augusto (2008), who show that a customer-oriented culture fosters a positive response among employees. The dimensions of human resource initiatives, consistent communications and brand personality also have a positive and significant influence on this 
outcome. These results are in line with the work by Punjaisri et al. (2009a), where identification is explained by internal marketing activities, which mainly refer to elements of internal communication and training. Corporate visual identity, by contrast, has an insignificant impact on employees' identification with the organisation. Therefore, in the light of the results obtained in this work, management of the corporate visual identity is not as important as the rest of the elements to foster organisational identification. Corporate visual identity might favour the attractiveness of brand identity amongst stakeholders (Bravo et al., 2015b). However, this may not directly affect employees' sense of identification with the organisation. This finding can also be explained by the operationalisation of the corporate visual identity dimension. As Coleman et al. (2015) note, the items used to measure this construct capture the main visual cues (i.e. font and logo), as well as consideration of the evoked recognition. However, there are other elements of the corporate visual identity not included.

Organisational identification in turn results in positive attitudes and behaviours, encouraging employees to become brand champions (Löhndorf and Diamantopoulos, 2014). The findings suggest that highly identified employees will be more satisfied. Likewise, employees who strongly identify with their organisations will be more likely to undertake brand citizenship behaviours which help their company. Job satisfaction, by contrast, does not predict brand citizenship behaviours. This result is consistent with previous research (e.g. Netemeyer et al., 1997) and indicates the importance of organisational identification as a determinant of extra-role activities aimed at strengthening brand identity and reaching the brand goals. Finally, the results show that employees can also be the senders of positive WOM and this behaviour is determined by their identification with their company and their job satisfaction.

\section{Theoretical implications}

The current study offers a number of theoretical contributions. Prior studies on brand identity management have mainly a theoretical approach or are based on case studies (e.g. Burmann et al., 2009a; da Silveira et al., 2013; Konecnik and de Chernatony, 2013). This study extends previous brand identity management research by providing empirical evidence on the construct of brand identity management and its influence on employees' attitudes and behaviours. 
Specifically, while much literature is available on what brand identity is, little research has been devoted to the development of measurement scales for this construct. This research offers additional insights into the conceptualisation and measurement of brand identity management through the application of one of the most recent scales developed in the literature (Coleman et al., 2011). The brand identity management conceptualisation overcomes the predominance of dimensions related to the visual identity elements and external communications, incorporating new factors such as employee and customer focus and brand personality (Simoes et al., 2005; Arendt and Brettel, 2010; Coleman et al., 2011). Likewise, there is a paucity of empirical research which explores the effects of brand identity management. As such, the positive impact of brand identity on brand performance and other outcomes is sometimes based on anecdotal claims (Coleman et al., 2015). An important contribution of this study is, therefore, to empirically analyse the impact of the different dimensions comprising the concept of brand identity management.

In addition, existing research primarily investigates the views of brand managers, senior marketing executives or external consultants (e.g. Suvatjis et al., 2012; Coleman et al., 2015), yet only a relatively small number of studies have examined the perspectives of employees. Employees are an important source of competitive advantage, especially in the services sector where customers usually have direct contact with staff. Therefore, this research provides insights into the effects of brand identity management from the perspective of employees, exploring their perceptions.

\section{Managerial implications}

This study provides several managerial implications. First, branding issues have not been high on the agenda of many service organisations and financial institutions (Wallace and de Chernatony, 2011), yet this study shows that branding and brand identity have important benefits for companies. Specifically, this research provides a model for managers in general, and financial services managers in particular, to anticipate employees' attitudes and behaviours on the basis of employees' perceptions of the dimensions of brand identity management. The importance of developing new models and metrics is growing for both practitioners and academics. This is particularly relevant in areas such as marketing and organisation management, where the environment changes rapidly and it is difficult to foresee precisely and immediately the impact of certain decisions (Zahay and Griffin, 2010; Klaus and Edvardsson, 2014). Specifically, it is common practice in management to seek models 
which predict stakeholders' behaviour. Most models focus on consumers' responses. However, they may also include other groups of interest such as employees, partners or society in general. The model tested in this study successfully explains key outcomes of employees' behaviour, such as employees' organisational identification, job satisfaction, employee WOM and brand citizenship behaviours. Therefore it can be used by managers to anticipate these outcomes in the light of employees' perceptions of brand identity management. Thus, we suggest organisations periodically monitor perceptions of brand identity management. This may facilitate the early detection of negative perceptions, enabling managers to implement changes before these perceptions result in inappropriate behaviours.

Internal monitoring of brand identity management involves focusing on several elements. Traditionally, managers have paid more attention to dimensions related to the human resources initiatives that are more directly related to employees or the tangible aspects of brand identity, such as visual identity. However, there are other essential components of the brand identity strategy which determine employees' attitudes and behaviours. The findings provide some insight into the relevance of these factors. Specifically, an employee-client focus is the dimension that exerts the strongest effect on employees' outcomes. As a result, managers should place more emphasis on this aspect of brand identity management, responding to their clients' needs, but also offering support to their employees. Organisations should also provide training that enables employees to deepen relationships with clients. Attention must also be paid to integrated marketing communications. This is a critical success factor in building strong brands and strong organisations. Therefore, managers should use these tools to present a consistent brand identity and foster employees' identification. Finally, managers should humanise their brands. Brand personality is a well-known vehicle of consumer self-expression, but can also help employees to identify themselves with their organisations.

By contrast, employees' perceptions of corporate visual identity management do not have a significant effect on the level of identification. However, the differential effect of the brand identity management dimensions and its importance should not be misinterpreted. Brand identity management has to be targeted to all stakeholders. This study has focused on the effects on employees' outcomes. In studies focused on other stakeholders, a consistent visual identity has been shown to be a relevant factor to increase brand awareness in consumers' minds. The implications from this work are, therefore, that brand identity management cannot be constrained to building a strong brand identity exclusively in the eyes of consumers. Its 
management has to be directed at all stakeholders, and its effects should be also measured in the light of every stakeholder's responses. As such, this work unveils internal effects on the employees that should not be overlooked. Given the importance of employees in services, either a positive or a negative effect on employees' behaviour may quickly impact consumers' responses (Evanschitzky et al., 2011).

Finally, financial services organisations have been held at least partly responsible for the economic crisis and their image has been seriously damaged during these years. The decrease in trust and credibility in banking institutions has fostered skepticism towards these organisations. As this study shows, brand identity management can be a useful strategic tool to foster positive employees' attitudes and behaviours. This might be, therefore, a good opportunity to encourage the participation of all their staff in the challenge of changing their corporate brand identity. This could foster a continuous dialogue, seeking to align the values between the organisation and employees, encouraging their contribution with new ideas to improve processes and services. If it is not possible to gain consensus, at least it is important to ensure that the brand identity and its management are correctly understood by all employees. This should help employees realise the importance of building a strong corporate brand, to gain a positive perception of its management. In addition, this could help to rebuild trust and forge strong relationships with consumers and society in general.

\section{Limitations and suggestions for future research}

This study has several limitations. The results need to be interpreted within the context of the UK financial services sector. Previous studies have shown dissimilarities in brand management between countries (Mabey, 2008; Bravo et al., 2013). Different segments of employees may also have distinct responses to the same management. Therefore, replication of the analysis in other sectors and countries could help regarding the generalisation of results. Testing the model amongst separate groups of employees may also shine light on possible differences between types of employees according to their demographic and psychographic characteristics or the bank for whom they work.

It is important to highlight the fact that the empirical study is cross-sectional. Information from each respondent regarding their perceptions, attitudes, and behaviours was obtained at one point in time. Consequently, a longitudinal framework would provide more insight into 
probable causation and facilitate better understanding of changes in brand identity management and possible consequences in employees' behaviour over time.

Another interesting line of research could be to extend the model including other elements that may influence brand identity management. Variables such as brand orientation, market orientation, or other organisational variables (Urde et al., 2013) could be of interest. In our study, employees' perceptions of brand authenticity and organisational support have not been explicitly considered and its inclusion in further research could help to understand the effects of employees' perceptions of brand identity management.

Future research could also be insightful through connecting the effects that brand identity management may have on different stakeholders. The relationship between the responses to different stakeholders is a promising path of study (Evanschitzky et al., 2012) and a dyadic perspective about brand identity management where employees' views and those of their clients are analysed could be a suitable complement for this study.

All in all, the results obtained in this work highlight the relevance of managing brand identity within organisations. Particularly after the economic shock from the global financial crisis, internal budgets and decisions about allocation of resources have to be based on facts, figures and evidences. This work unveils advantages of a brand identity management tool and provides support for the central role of brand identity in the management of an organisation.

\section{References}

Aaker, D.A. (1996), Building Strong Brands, The Free Press, New York.

Ahearne, M., Bhattacharya, C.B. and Gruen, T. (2005), "Antecedents and consequences of customer-company identification: Expanding the role of relationship marketing", Journal of Applied Psychology, Vol. 90 No. 3, pp. 574-585.

Albert, S. and Whetten, D.A. (1985), “Organizational identity”, in L.L. Cummings and B.M. Staw (Eds.), Research in Organizational Behavior, Vol. 7, CT: JAI Press, Greenwich, pp. 263-295.

Algesheimer, R., Dholakia, U.M. and Herrmann, A. (2005), "The social influence of brand community: Evidence from European car clubs", Journal of Marketing, Vol. 69 No. 3, pp. 19-34. 
Alloza, A. (2008), "Brand engagement and brand experience at BBVA, the transformation of a 150 years old company”, Corporate Reputation Review, Vol. 11 No. 4, pp. 371-379.

Arendt, S. and Brettel, M. (2010), "Understanding the influence of corporate social responsibility on corporate identity, image, and firm performance", Management Decision, Vol. 48 No. 10, pp. 1469-1492.

Arndt, J. (1967), "Role of product-related conversations in the diffusion of a new product", Journal of Marketing Research, Vol. 4, 291-295.

Ashforth, B.E. and Mael, F. (1989), "Social identity theory and the organization", Academy of Management Review, Vol. 14 No. 1, pp. 20-39.

Berger, I.E., Cunningham, P.H. and Drumwright, M.E. (2006), "Identity, identification, and relationship through social alliances", Journal of the Academy of Marketing Science, Vol. 34 No. 2, pp. 128-137.

Bhattacharya, C.B. and Sen, S. (2003), "Consumer-company identification: A framework for understanding consumers' relationships with companies”, Journal of Marketing, Vol. 67 No 2, pp. 76-88.

Boone, M. (2000), “The importance of internal branding”, Sales and Marketing Management, Vol. 9, pp. 36-38.

Bravo, R., de Chernatony, L., Matute, J. and Pina, J.M. (2013), "Projecting banks' identities through corporate websites: A comparative analysis of Spain and the United Kingdom", Journal of Brand Management, Vol. 20 No. 7, pp. 533-557.

Bravo, R., Matute, J. and Pina, J.M. (2015a), "Corporate identity management and employees' responses", Journal of Strategic Marketing, DOI: 10.1080/0965254X.2015.1076876

Bravo, R., Matute, J. and Pina, J.M. (2015b), “Corporate identity management in the banking sector: effects on employees' identification, identity attractiveness, and job satisfaction”, Service Business, DOI: 10.1007/s11628-015-0287-9

Brief, A.P. (1998), Attitudes In and Around Organizations, Sage, Thousand Oaks, CA.

Brown, T.J., Barry, T.E., Dacin, P.A. and Gunst, R.F. (2005), "Spreading the word: Investigating antecedents of consumers' positive word-of-mouth intentions and behaviors 
in a retailing context", Journal of the Academy of Marketing Science, Vol. 33 No. 2, pp. 123-138.

Burmann, C. and Zeplin, S. (2005), "Building brand commitment: A behavioural approach to internal brand building”, Journal of Brand Management, Vol. 12 No. 4, pp. 279-300.

Burmann, C., Jost-Benz, M. and Riley, N. (2009a), "Towards an identity-based brand equity model”, Journal of Business Research, Vol. 62, pp. 390-397.

Burmann, C., Zeplin, S. and Riley, N. (2009b), "Key determinants of internal brand management success: An exploratory empirical analysis". Journal of Brand Management, Vol. 16 No. 4, pp. 264-284.

Carter, D.E. (1982), Designing Corporate Identity Programs for Small Corporations, Art Direction Company, New York, NY.

Chin, W.W. (2010), How to write up and report PLS analyses, In Handbook of Partial Least Squares (pp. 655-690), Springer Berlin Heidelberg.

Coelho, F. and Augusto, M. (2008), "Organizational factors associated with job characteristics: evidence from frontline service employees", Journal of Strategic Marketing, Vol. 16 No. 2, pp. 157-172.

Coleman, D., de Chernatony, L. and Christodoulides, G. (2011), "B2B service brand identity: Scale development and validation”, Industrial Marketing Management, Vol. 40 No. 7, pp. 1063-1071.

Coleman, D., de Chernatony, L. and Christodoulides, G. (2015), "B2B service brand identity and brand performance: an empirical investigation in the UK's B2B IT services sector", European Journal of Marketing, Vol. 49 No. 7/8, pp. 1139-1162.

Colton, S. and Oliveira, P. (2009), "Banking on it: The role of the corporate brand in rebuilding trust", Interbrand. Available at: http://www.interbrand.com/Libraries/Articles/1_IP_Banking_on_it_pdf.sflb.ashx (accessed 23 July 2015).

da Silveira, C., Lages, C. and Simoes, C. (2013), "Reconceptualizing brand identity in a dynamic environment”, Journal of Business Research, Vol. 66 No 1, pp. 28-36.

Daffey, A. and Abratt, R. (2002), "Corporate branding in a banking environment", Corporate Communications, Vol. 7 No. 2, pp. 87-91. 
Davies, G. (2008), "Employer branding and its influence on managers”, European Journal of Marketing, Vol. 42 No. 5/6, pp. 667-681.

de Chernatony, L. (2010), From Brand Vision to Brand Evaluation (3rd ed.), ButterworthHeinemnn, Oxford.

Du Preez, R. and Bendixen, M.T. (2015), “The impact of internal brand management on employee job satisfaction, brand commitment and intention to stay", International Journal of Bank Marketing, Vol. 33 No. 1, pp. 78-91.

Dukerich, J.M., Golden, B.R. and Shortell, S.M. (2002), "Beauty is in the eye of the beholder: The impact of organizational identification, identity, and image on the cooperative behaviors of physicians", Administrative Science Quarterly, Vol. 47, pp. 507-533.

Dutton, J., Dukerich, J. and Harquail, C. (1994), "Organizational images and member identification", Administrative Science Quarterly, Vol. 39 No 2, pp. 239-263.

Evanschitzky, H., Groening, C., Mittal, V. and Wunderlich, M. (2011), "Customer, employee, and employee satisfaction in franchise networks: a generalized exchange perspective", Journal of Service Research, Vol. 14 No. 2, pp. 136-148.

Evanschitzky, H., Wangenheim, F. and Wünderlich, N. (2012), "Perils of managing the service profit chain: The role of time lags and feedback loops", Journal of Retailing, Vol. 88 No. 3, pp. 356-366.

Falk, R.F. and Miller, N.B. (1992), A Primer for Soft Modeling, The University of Akron, . Akron, Ohio.

Fornell, C. and Larcker, D.F. (1981), "Evaluating structural equation models with unobservable variables and measurement error", Journal of Marketing Research, Vol. 18 No. 1, pp. 39-50.

Ghodeswar, B.M. (2008), "Building brand identity in competitive markets: a conceptual model”, Journal of Product and Brand Management, Vol. 17 No. 1, pp. 4-12.

Gremler, D.D., Gwinner, K.P. and Brown, S.W. (2001), “Generating positive word-of-mouth communication through customer-employee relationships", International Journal of Service Industry Management, Vol. 12 No. 1, pp. 44-59.

Hackman, J.R. and Oldham, G.R. (1980), Work Redesign. Addison-Wesley, Reading, MA. 
Hair, J.F., Black, W.C., Babin, B.J. and Anderson, R.E. (2010), Multivariate Data Analysis, $7^{\text {th }}$ edition, Prentice-Hall, London.

Hair, J.F., Ringle, C.M. and Sarstedt, M. (2011), "PLS-SEM: Indeed a silver bullet”, The Journal of Marketing Theory and Practice, Vol. 19 No. 2, pp. 139-152.

Harris, F. and de Chernatony, L. (2001), "Corporate branding and corporate brand performance”, European Journal of Marketing, Vol. 35 No. 3/4, pp. 441-456.

Homans, G.C. (1958), “Social Behavior as Exchange”, American Journal of Sociology, Vol. 63 No. 6, pp. 597-606.

Isen, A.M. and Baron, R.A. (1991), "Positive affect as a factor in organizational behaviour", Research in Organizational Behavior, Vol. 13, pp. 1-53.

Johansson, J.K. and Carlson, K.A. (2014), Contemporary Brand Management, SAGE Publications.

Johnson, M. and Zinkhan, G.M. (1990), "Defining and measuring company image", Thirteenth Annual Conference of the Academy of Marketing Science, New Orleans, LA, Academy of Marketing Science.

Kapferer, J.N. (2012), The New Strategic Brand Management. Creating and Sustaining Brand Equity Long Term, $5^{\text {th }}$ ed., Kogan Page, London.

Keeling, K.A., McGoldrick, P.J. and Sadhu, H. (2013), "Staff Word-of-Mouth (SWOM) and retail employee recruitment", Journal of Retailing, Vol. 89 No. 1, pp. 88-104.

Kimpakorn, N. and Tocquer, G. (2010), "Service brand equity and employee brand commitment”, Journal of Services Marketing, Vol. 24 No. 5, pp. 378-388.

King, C. and Grace, D. (2010), "Building and measuring employee-based brand equity", European Journal of Marketing, Vol. 44 No. 7, pp. 938-971.

King, C. and Grace, D. (2012), "Examining the antecedents of positive employee brandrelated attitudes and behaviours", European Journal of Marketing, Vol. 46 No. 3/4, pp. 469-488.

Klaus, P. and Edvardsson, B. (2014), “The road back to relevance: How to put marketing (and marketing scholars) back on the Top Managements' agendas", Journal of Service Management, Vol. 25 No. 2, pp. 166-170. 
Konecnik, M. and de Chernatony, L. (2013), "Developing and applying a place brand identity model: The case of Slovenia”, Journal of Business Research, Vol. 66 No. 1, pp. 45-52.

Kuehner-Herbert, K.A. (2009), “A growing defection issue: More clients ready to switch as trust wanes", American Banker: The Financial Services Daily. Available at: www.financial-planning.com/news/clients-distrust-banks-2661954-1.html (accessed 23 May 2015).

Kuenzel, S. and Halliday, S.V. (2008), "Investigating antecedents and consequences of brand identification", Journal of Product and Brand Management, Vol. 17 No. 5, pp. 293-304.

Lages, C.R. (2012), “Employees' external representation of their workplace: key antecedents", Journal of Business Research, Vol. 65 No. 9, pp. 1264-1272.

Lee, K. and Allen, N.J. (2002), "Organizational citizenship behavior and workplace deviance: the role of affect and cognitions", Journal of Applied Psychology, Vol. 87 No. 1, pp. 131142.

Library of the House of Commons (2015), "Financial Services: contribution to the UK economy", available at http://www.parliament.uk/briefing-papers/sn06193.pdf (accessed 23 May 2015).

Locke, E.A. (1969), "What is job satisfaction?", Organizational Behavior and Human Performance, Vol. 4 No. 4, pp. 309-336.

Löhndorf, B. and Diamantopoulos, A. (2014), "Internal branding. Social identity and social exchange perspectives on turning employees into brand champions", Journal of Service Research, DOI: 10.1177/1094670514522098

Mabey, C. (2008), "Management development and firm performance in Germany, Norway, Spain and the UK”, Journal of International Business Studies, Vol. 39 No. 8, pp. 13271342.

Mael, F. and Ashforth, B.E. (1992), “Alumni and their alma mater: A partial test of the reformulated model of organizational identification”, Journal of Organizational Behavior, Vol. 13 No. 2, pp. 103-123.

Melewar, T.C. and Akel, S. (2005), "The role of corporate identity in the higher education sector: A case study", Corporate Communications: An International Journal, Vol. 10 No. 1, pp. 41-57. 
Mitki, Y., Herstein, R. and Jaffe, E.D. (2007), "Learning mechanisms for designing corporate identity in the banking industry", International Journal of Bank Marketing, Vol. 25 No.7 pp. 452-468.

Mukherjee, A. and He, H.W. (2008), "Company identity and marketing: an integrative framework", Journal of Marketing Theory and Practice, Vol. 16 No. 2, pp. 111-125.

Murphy, G., Athanasou, J. And King, N. (2002), "Job satisfaction and organizational citizenship behaviour: A study of Australian human-service professionals", Journal of Managerial Psychology, Vol. 17 No. 4, pp. 287-297.

Netemeyer, R.G., Boles, J.S., McKee, D.O. and McMurrian, R. (1997), “An investigation into the antecedents of organizational citizenship behaviors in a personal selling context", Journal of Marketing, Vol. 61 No. 3, pp. 85-98.

Organ, D.W. (1988), Organizational Citizenship Behaviour: The Good Soldier Syndrome, Ed. Lexington-Books, Lexington, MA.

Papasolomou, I. and Vrontis, D. (2006), "Building corporate branding through internal marketing: the case of the UK retail bank industry", Journal of Product \& Brand Management, Vol. 15No. 1, pp. 37-47.

Pérez, A. and Rodríguez del Bosque, I. (2012), "The role of CSR in the corporate identity of banking service providers", Journal of Business Ethics, Vol. 108 No. 2, pp 145-166.

Podsakoff, P.M., MacKenzie, S.B., Lee, J.Y. and Podsakoff, N.P. (2003), "Common method biases in behavioral research: A critical review of the literature and recommended remedies", Journal of Applied Psychology, Vol. 88, pp. 879-903.

Punjaisri, K. and Wilson, A. (2011), "Internal branding process: Key mechanisms, outcomes and moderating factors", European Journal of Marketing, Vol. 45 No. 9, pp. 1521-1537.

Punjaisri, K., Evanschitzky, H. and Wilson, A. (2009a), "Internal branding: an enabler of employees' brand-supporting behaviours", Journal of Service Management, Vol. 20 No. 2, pp. 209-226.

Punjaisri, K., Wilson, A. and Evanschitzky, H. (2009b), "Internal branding to influence employees' brand promise delivery: a case study in Thailand", Journal of Service Management, Vol. 20 No. 5, pp. 561-579. 
Reinartz, W., Haenlein, M. and Henseler, J. (2009), “An empirical comparison of the efficacy of covariance-based and variance-based SEM", International Journal of Research in Marketing, Vol. 26, pp. 332-344.

Riketta, M. (2005), "Organizational identification: A meta-analysis", Journal of Vocational Behavior, Vol. 66 No. 2, pp. 358-384.

Riketta, M. (2008), "The causal relation between job attitudes and performance: a metaanalysis of panel studies", Journal of Applied Psychology, Vol. 93 No. 2, pp. 472-481.

Schlager, T., Bodderas, M., Maas, P. and Luc Cachelin, J. (2011), "The influence of the employer brand on employee attitudes relevant for service branding: an empirical investigation", Journal of Services Marketing, Vol. 25 No. 7, pp. 497-508.

Searle, M.S. (1990), "Social Exchange Theory as a Framework for Understanding Ceasing Participation in Organized Leisure Activities", Bryan J.A. Smale (Ed.), Proceedings of the Sixth Canadian Congress on Leisure Research, May, pp. 9-12.

Shaari, H., Salleh, S.M. and Hussin, Z. (2012), "Relationship between brand knowledge and brand rewards, and employees' brand citizenship behavior: the mediating roles of brand commitment", International Journal of Business and Society, Vol. 13 No. 3, pp. 335-354.

Simoes, C., Dibb, S. and Fisk, R. (2005), "Managing corporate identity: An internal perspective", Journal of the Academy of Marketing Science, Vol. 33 No. 2, pp. 153-169.

Suvatjis, J., de Chernatony, L. and Halikias, J. (2012), "Assessing the six-station corporate identity model: a polymorphic model”, Journal of Product \& Brand Management, Vol. 21 No. 3, pp. 153-166.

Tajfel, H. and Turner, J. (1979), "An integrative theory of intergroup conflict”, in A.William and S. Worchel (eds.), The Social Psychology of Intergroup Relations, Monterey, CA: Brooks/Cole, pp. 33-47.

Tuskej, U., Golob, U. and Podnar, K. (2013), "The role of consumer-brand identification in building brand relationships", Journal of Business Research, Vol. 66 No. 1, pp. 53-59.

Urde, M., Baumgarth, C. and Merrilees, B. (2013), "Brand orientation and market orientation-From alternatives to synergy", Journal of Business Research, Vol. 66 No. 1, pp. 13-20. 
Van Dick, R., Christ, O., Stellmacher, J., Wagner, U., Ahlswede, O., Grubba, C., Hauptmeier, M., Höhfeld, C., Moltzen, K. and Tissington, P.A. (2004), "Should I stay or should I go? Explaining turnover intentions with organizational identification and job satisfaction", British Journal of Management, Vol. 15 No. 4, pp. 351-360.

Van Dick, R., Grojean, M.W., Christ, O. and Wieseke, J. (2006), "Identity and the extra mile: Relationships between organizational identification and organizational citizenship behaviour", British Journal of Management, Vol. 17 No. 4, pp. 283-301.

Van Dick, R., van Knippenberg, D., Kerschreiter, R., Hertel, G., and Wieseke, J. (2008), "Interactive effects of work group and organizational identification on job satisfaction and extra-role behavior", Journal of Vocational Behavior, Vol. 72 No. 3, pp. 388-399.

Van Knippenberg, D. (2000), "Work motivation and performance: a social identity perspective", Applied Psychology: An International Review, Vol. 49 No. 3, pp. 357-371.

Van Riel, C. (1995), Principles of Corporate Communication, Ed. Prentice-Hall, London, UK.

Wallace, E. and de Chernatony, L. (2011), "The influence of culture and market orientation on services brands: insights from Irish banking and retail firms", Journal of Services Marketing, Vol. 25 No. 7, pp. 475-488.

Wheeler, A.R., Richey, G., Tokkman, M. and Sablynski, C.J. (2006), "Retaining employees for service competency: The role of corporate brand identity", Journal of Brand Management, Vol. 14 No. 1/2, pp. 96-113.

Wu, C.H.J., Liang, R.D., Tung, W. and Chang, C.S. (2008), "Structural relationships among organisation service orientation, employee service performance, and consumer identification", The Service Industries Journal, Vol. 28, pp. 1247-1263.

Zahay, D. and Griffin, A. (2010), "Marketing strategy selection, marketing metrics, and firm performance”, Journal of Business and Industrial Marketing, Vol. 25 No. 2, pp. 84-93. 
Figure 1. Proposed model

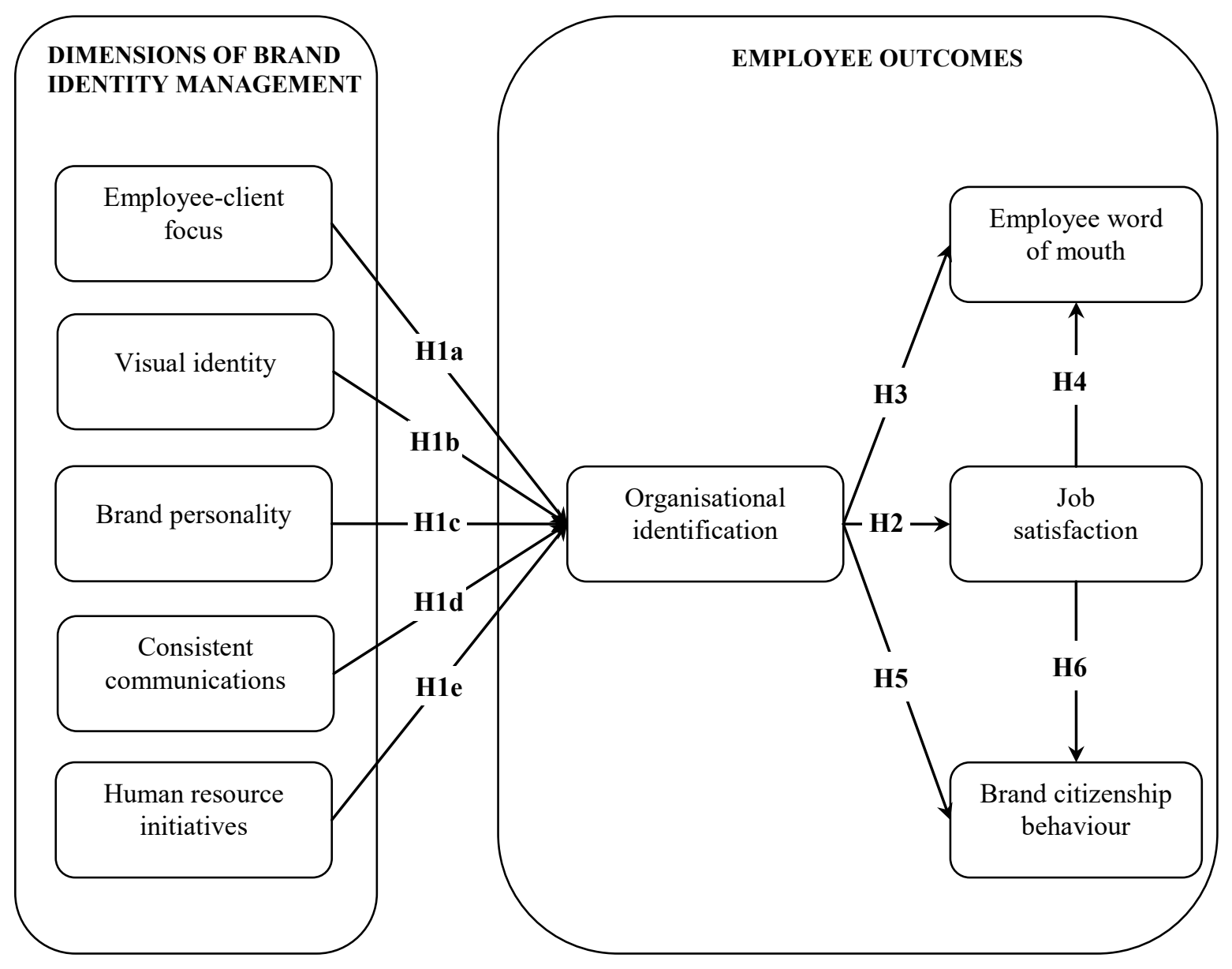


Figure 2. Structural model results

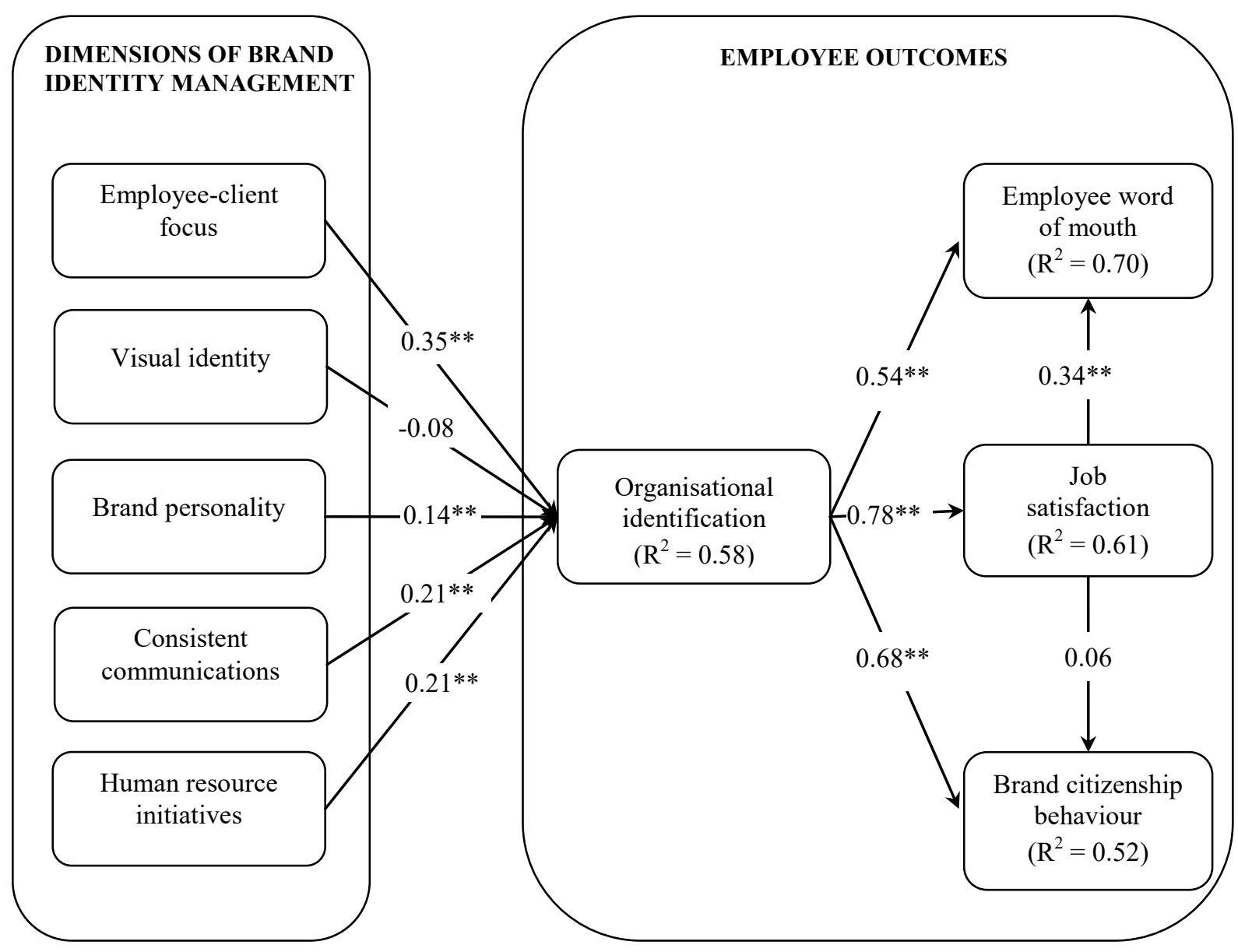

Note: ** significant at $\mathrm{p}<0.05$ 
Table 1: Sample characteristics

\begin{tabular}{|c|c|}
\hline Gender & $\begin{array}{l}\text { Men: } 46.8 \% \\
\text { Women: } 53.2 \%\end{array}$ \\
\hline Age & $\begin{array}{l}\text { From } 18 \text { to } 24: 7.1 \% \\
\text { From } 25 \text { to } 34: 35 \% \\
\text { From } 35 \text { to } 44: 34 \% \\
\text { From } 45 \text { to } 67: 23.9 \%\end{array}$ \\
\hline Employment status & $\begin{array}{l}\text { Full time: } 84.5 \% \\
\text { Part time: } 15.5 \%\end{array}$ \\
\hline Experience in the bank & $\begin{array}{l}\text { From } 1 \text { to } 5 \text { years: } 41 \% \\
\text { From } 6 \text { to } 10 \text { years: } 21 \% \\
\text { From } 11 \text { to } 20 \text { years: } 20 \% \\
\text { More than } 20 \text { years: } 18 \%\end{array}$ \\
\hline
\end{tabular}


Table 2: Scale composition

\begin{tabular}{|c|c|}
\hline \multicolumn{2}{|r|}{ BRAND IDENTITY MANAGEMENT (Coleman et al., 2011) } \\
\hline \multicolumn{2}{|r|}{ Employee-client focus } \\
\hline EC1 & Our top management is committed to providing quality service \\
\hline EC2 & Our bank treats every employee as an essential part of the organisation \\
\hline EC3 & Our employees will help clients in a responsive manner \\
\hline EC4 & Our bank makes an effort to discover our clients' needs \\
\hline EC5 & Our bank responds to our clients' needs \\
\hline \multicolumn{2}{|r|}{ Visual identity } \\
\hline VI1 & The corporate visual identity is helpful in making our bank recognisable \\
\hline VI2 & The font we use is an important part of our visual identity \\
\hline VI3 & Our logo is an important part of who we are \\
\hline \multicolumn{2}{|r|}{ Brand personality } \\
\hline PER1 & The associations making up our brand personality are extremely positive \\
\hline PER2 & Our clients have no difficulty describing our brand personality \\
\hline PER3 & Our brand personality has favourable associations \\
\hline \multicolumn{2}{|r|}{ Consistent communications } \\
\hline COM1 & $\begin{array}{l}\text { The people managing our communications programme have a good understanding of the } \\
\text { strengths and weaknesses of all major marketing communications tools }\end{array}$ \\
\hline COM2 & $\begin{array}{l}\text { Our bank's advertising, PR and sales promotion all present the same clear consistent } \\
\text { message to our stakeholders }\end{array}$ \\
\hline \multicolumn{2}{|r|}{ Human resource initiatives } \\
\hline HR1 & $\begin{array}{l}\text { Our employee training programmes are designed to develop skills required for acquiring } \\
\text { and deepening client relationships }\end{array}$ \\
\hline HR2 & Our bank regularly monitors employees' performance \\
\hline \multicolumn{2}{|r|}{ ORGANISATIONAL IDENTIFICATION (Based on Punjaisri et al., 2009a) } \\
\hline OI1 & I feel I belong to this bank \\
\hline OI2 & I view the success of the bank as my own success \\
\hline OI3 & When someone praises this bank, it feels like a personal compliment \\
\hline \multicolumn{2}{|r|}{ JOB SATISFACTION (Based on King and Grace, 2010) } \\
\hline SAT1 & I feel reasonably satisfied with my job \\
\hline SAT2 & I feel a great sense of satisfaction from my job \\
\hline SAT3 & I am satisfied with my overall job \\
\hline \multicolumn{2}{|r|}{ EMPLOYEE WORD-OF-MOUTH (Based on King and Grace, 2010) } \\
\hline WOM1 & I say positive things about my bank to others \\
\hline WOM2 & I would recommend my bank to someone who seeks my advice \\
\hline WOM3 & I enjoy talking about my bank to others \\
\hline WOM4 & I talk positively about my bank to others \\
\hline \multicolumn{2}{|r|}{$\begin{array}{l}\text { BRAND CITIZENSHIP BEHAVIOUR (Based on Burmann and Zeplin, 2005; and King and Grace, } \\
\text { 2010) }\end{array}$} \\
\hline BCB1 & I demonstrate behaviours that are consistent with the brand promise of this bank \\
\hline$B C B 2$ & I am always interested to learn about my bank's brand and what it means for me in my role \\
\hline$B C B 3$ & Before communicating or taking action I consider the impact on my bank's brand \\
\hline$B C B 4$ & If given the opportunity, I pass on my knowledge about my bank's brand to new employees \\
\hline BCB5 & $\begin{array}{l}\text { I show extra initiative to ensure that my behaviour remains consistent with the brand } \\
\text { promise of this bank }\end{array}$ \\
\hline$B C B 6$ & $\begin{array}{l}\text { I take responsibility for tasks outside of my own area if necessary, e.g. following up on } \\
\text { customer requests etc }\end{array}$ \\
\hline
\end{tabular}


Table 3: Measurement model results

\begin{tabular}{|c|c|c|c|c|c|c|c|c|c|}
\hline $\begin{array}{l}\text { BRAND IDENTITY } \\
\text { MANAGEMENT }\end{array}$ & $\lambda$ & Alpha & CR & AVE & OUTCOMES & $\lambda$ & Alpha & CR & AVE \\
\hline $\begin{array}{l}\text { Employee-client focus } \\
\text { (EC) }\end{array}$ & & & & & $\begin{array}{l}\text { Organisational } \\
\text { identification (OI) }\end{array}$ & & & & \\
\hline $\begin{array}{l}E C 1 \\
E C 2 \\
E C 3 \\
E C 4 \\
E C 5 \\
\end{array}$ & $\begin{array}{l}0.87^{*} \\
0.86^{*} \\
0.90^{*} \\
0.93^{*} \\
0.93^{*} \\
\end{array}$ & 0.94 & 0.96 & 0.81 & $\begin{array}{l}\text { OI1 } \\
\text { OI2 } \\
\text { OI3 }\end{array}$ & $\begin{array}{l}0.93^{*} \\
0.95^{*} \\
0.93^{*}\end{array}$ & 0.93 & 0.96 & 0.88 \\
\hline Visual identity (VI) & & & & & $\begin{array}{l}\text { Job satisfaction } \\
\text { (SAT) }\end{array}$ & & & & \\
\hline $\begin{array}{l}\text { VI1 } \\
\text { VI2 } \\
\text { VI3 } \\
\end{array}$ & $\begin{array}{l}0.91^{*} \\
0.87^{*} \\
0.90^{*}\end{array}$ & 0.87 & 0.92 & 0.80 & $\begin{array}{l}\text { SAT1 } \\
\text { SAT2 } \\
\text { SAT3 }\end{array}$ & $\begin{array}{l}0.97^{*} \\
0.97^{*} \\
0.97^{*}\end{array}$ & 0.97 & 0.98 & 0.94 \\
\hline $\begin{array}{l}\text { Brand personality } \\
\text { (PER) }\end{array}$ & & & & & $\begin{array}{l}\text { Employee word-of- } \\
\text { mouth (WOM) }\end{array}$ & & & & \\
\hline $\begin{array}{l}\text { PER1 } \\
\text { PER2 } \\
\text { PER3 }\end{array}$ & $\begin{array}{l}0.91^{*} \\
0.92^{*} \\
0.91^{*}\end{array}$ & 0.90 & 0.94 & 0.84 & $\begin{array}{l}\text { WOM1 } \\
\text { WOM2 } \\
\text { WOM3 } \\
\text { WOM4 }\end{array}$ & $\begin{array}{l}0.94^{*} \\
0.95^{*} \\
0.90^{*} \\
0.96^{*}\end{array}$ & 0.96 & 0.97 & 0.88 \\
\hline $\begin{array}{l}\text { Consistent } \\
\text { communications } \\
\text { (COM) }\end{array}$ & & & & & $\begin{array}{l}\text { Brand citizenship } \\
\text { behaviour (BCB) }\end{array}$ & & & & \\
\hline $\begin{array}{l}\text { COM1 } \\
\text { COM2 }\end{array}$ & $\begin{array}{l}0.94^{*} \\
0.95^{*}\end{array}$ & 0.88 & 0.95 & 0.90 & \multirow{3}{*}{$\begin{array}{l}B C B 1 \\
B C B 2 \\
B C B 3 \\
B C B 4 \\
B C B 5 \\
B C B 6\end{array}$} & \multirow{3}{*}{$\begin{array}{l}0.84^{*} \\
0.90^{*} \\
0.87^{*} \\
0.88^{*} \\
0.91^{*} \\
0.79^{*}\end{array}$} & \multirow[t]{3}{*}{0.93} & \multirow[t]{3}{*}{0.95} & \multirow[t]{3}{*}{0.75} \\
\hline $\begin{array}{l}\text { Human resources } \\
\text { initiatives (HR) }\end{array}$ & & & & & & & & & \\
\hline $\begin{array}{l}H R 1 \\
H R 2\end{array}$ & \begin{tabular}{l|l|}
$0.92^{*}$ \\
$0.81^{*}$
\end{tabular} & 0.68 & 0.86 & 0.75 & & & & & \\
\hline
\end{tabular}

Note: $*=$ significant at $\mathrm{p}<0.001 ; \lambda$ : Standardised factor loading; Alpha: Cronbach's Alpha; CR: Composite Reliability; AVE: Average Variance Extracted. 
Table 4: Discriminant validity results

\begin{tabular}{|l|c|c|c|c|c|c|c|c|c|}
\hline & EC & VI & PER & COM & HR & OI & SAT & WOM & BCB \\
\hline Employee-client focus (EC) & $\mathbf{0 . 8 1}$ & & & & & & & & \\
\hline Visual identity (VI) & 0.41 & $\mathbf{0 . 8 0}$ & & & & & & & \\
\hline Brand personality (PER) & 0.51 & 0.40 & $\mathbf{0 . 8 4}$ & & & & & & \\
\hline Consistent communications (COM) & 0.43 & 0.27 & 0.43 & $\mathbf{0 . 9 0}$ & & & & & \\
\hline Human resources initiatives (HR) & 0.37 & 0.24 & 0.33 & 0.44 & $\mathbf{0 . 7 5}$ & & & & \\
\hline Organisational identification (OI) & 0.47 & 0.21 & 0.38 & 0.42 & 0.40 & $\mathbf{0 . 8 8}$ & & & \\
\hline Job satisfaction (SAT) & 0.37 & 0.15 & 0.33 & 0.28 & 0.33 & 0.61 & $\mathbf{0 . 9 4}$ & & \\
\hline Employee word-of-mouth (WOM) & 0.50 & 0.24 & 0.45 & 0.40 & 0.41 & 0.66 & 0.59 & $\mathbf{0 . 8 8}$ & \\
\hline Brand citizenship behavior (BCB) & 0.45 & 0.28 & 0.34 & 0.46 & 0.35 & 0.53 & 0.35 & 0.53 & $\mathbf{0 . 7 5}$ \\
\hline
\end{tabular}

Note: Figures in the diagonal present the AVE values. Off-diagonal figures represent the constructs' squared correlations. 
Table 5: Results of hypothesis tests

\begin{tabular}{|c|c|c|c|}
\hline Hypotheses & $\beta(t)$ & $\mathbf{Q}^{2}$ & $\mathbf{R}^{2}$ \\
\hline H1a Employee-client focus $\rightarrow$ Organisational identification & $0.35^{* *}(4.62)$ & \multirow{10}{*}{$\begin{array}{c}\text { EC: } 0.70 \\
\text { VI: } 0.56 \\
\text { PER: } 0.63 \\
\text { COM: } 0.57 \\
\text { HR: } 0.26 \\
\text { OI: } 0.50 \\
\text { SAT: } 0.53 \\
\text { WOM: } 0.58 \\
\text { BCB: } 0.36\end{array}$} & \multirow{10}{*}{$\begin{array}{c}\text { OI: } 0.58 \\
\text { SAT: } 0.61 \\
\text { WOM: } 0.70 \\
\text { BCB: } 0.52\end{array}$} \\
\hline H1b Visual identity $\rightarrow$ Organisational identification & $-0.08(1.16)$ & & \\
\hline H1c Brand personality $\rightarrow$ Organisational identification & $0.14 * *(1.98)$ & & \\
\hline H1d Consistent communications $\rightarrow$ Organisational identification & $0.21 * *(2.59)$ & & \\
\hline H1e Human resources initiatives $\rightarrow$ Organisational identification & $0.21 * *(3.21)$ & & \\
\hline H2 Organisational identification $\rightarrow$ Job satisfaction & $0.78 * *(28.50)$ & & \\
\hline H3 Organisational identification $\rightarrow$ Employee word-of-mouth & $0.54 * *(8.90)$ & & \\
\hline H4 Job satisfaction $\rightarrow$ Employee word-of-mouth & $0.34 * *(5.31)$ & & \\
\hline H5 Organisational identification $\rightarrow$ Brand citizenship behaviour & $0.68 * *(9.82)$ & & \\
\hline H6 Job satisfaction $\rightarrow$ Brand citizenship behaviour & $0.06(0.74)$ & & \\
\hline
\end{tabular}

Note: $* *$ significant at $\mathrm{p}<0.05$ 